\title{
Feeding Behaviour and Functional Role of Some Selected Species of Brachyuran Crabs in Nutrient Cycle at Coastal Belt of Midnapore (East), West Bengal, India
}

\author{
Subhasish Chatterjee \\ Department of Zoology, Vidyasagar University \\ Midnapore-721102, West Bengal, India
}

Susanta Kumar Chakraborty (Corresponding author)

Department of Zoology, Vidyasagar University

Midnapore-721102, West Bengal, India

Tel: 91-943-327-0591Ｅ-mail: susantachakraborty@yahoo.com

Received: December 15, 2013 Accepted: December 31, 2013

doi:10.5296/jbls.v5i1.4869 URL: http://dx.doi.org/10.5296/jbls.v5i1.4869

\begin{abstract}
Studies on diet varieties and feeding activities of ten species of brachyuran crabs and their contribution in the nutrient cycle at coastal belt of Midnapore (East), West Bengal, India has established the significant roles played by grapsidae crabs Sesarma (Chiromantes) bidens, $S$. taeniolatum and Metopograpsus maculatus along with other brachyurans viz. Uca acuta acuta, $U$. lactea annulipes, U. triangularis bengali, Ocypoda macrocera, Dotilla blanfordi, Dotillopsis brevitarsis and Metaplax intermedia. Organic matter especially the mangrove plant litters after being processed by crabs could form the basis of a coprophagous food chain involving small invertebrates, or be re-exported as micro-particulates. Different nutrient contents viz. organic carbon, available phosphorus, available potassium and available nitrogen analyzed from the gut contents, excavated soils and soils surrounding burrows of the studied brachyuran species were found to show seasonal variability's and also significant differences among different species.
\end{abstract}

Keywords: Brachyuran crabs, Detritus, Gut content, Nutrient cycle 


\section{Introduction}

Unlike most intertidal benthic fauna, brachyuran crabs are semi-terrestrial and very active at low tides, returning to their burrows at high tide. They play a significant positive role in maintaining the steady state of the ecosystem and enhance its biological potentiality. Brachyuran crabs constituting an important faunal component in the food web of the coastal belt, play a significant role in accelerating the decomposition cycle as a macro decomposers influencing the ecosystem function to a large extent and are morphologically, physiologically and behaviorally well adapted to their environment. The burrow is a very important resource for the crabs (Crane, 1975; Zeil and Layne, 2002). It offers protection from aquatic predators during high tide and from aerial and terrestrial predators during low tide, when the crabs are active on the surface. The burrow protects the crabs from desiccation during their activities on the surface by offering them access to water, which is needed for respiration and feeding. The walls of the burrows are important sites for nitrification and de-nitrification processes in the sediment. Brachyuran crabs excavate and maintain semi-permanent open burrows, and remove large amount of sediments during feeding and burrow maintenance forming a surface mound around burrows (Iribarne et al., 1997; Botto \& Iribarne, 2000). Their burrowing habits assist in oxidizing the sulphides that build up, due to the high rates of organic decomposition (Holmboe \& Kristensen, 2001) \& also such activities directly break \& transport sediments \& decrease the hardness of the soil (Botto et al., 2005), modify micro-topography, \& increase the density of coarse particles on the soil surface (Warren \& Underwood, 1986). It is boldly recognized that coastal \& estuarine food chains are based to a significant extent on detritus \& dissolved organic matters produced from the breakdown of rooted \& attached macrophytes of intertidal \& shallow subtidal habitats. Burrow construction \& maintenance, ventilation \& import of organic matters play a significant role in energy flow \& nutrient cycling in coastal system (Alongi, 1990; Dworschak et al., 1993). Burrowing crabs significantly affect belowground processes that influence marsh plants in at least three ways viz. first, crab's burrowing increases the passage of liquid and gas within the soils to a considerable depth, enhance soil oxidation (Daleo \& Iribarne, 2009) and also the decomposition rate of organic debris (Fanjul et al., 2007); second, crab's burrows can selectively trap sediments that have high organic matter concentrations, finer grain size and low density through the interactions of the burrow openings with tidal water, which facilitate sedimentation and organic matter decomposition, increase nutrient availability and promote the growth of algae and other microorganism (Iribarne et al., 1997; Botto et al., 2006); third, excavation of burrows by crabs transports soil and nutrients from deep layers to the marsh surface, which might accelerate the turnover of soil and nutrients (Fanjul et al., 2008).

The crab communities of mangrove forests with Avicennia marina were dominated by microphagus ocypodid species (species that feed on detritus) rather than the leaf-eating sesarmid crabs found in the other forest types (Robertson and Daniel, 1989). Decomposition within the mangrove forest accounts for $20-70 \%$ of litter fall, depending on frequency of tidal inundation. Crab consumed greater than $78 \%$ of the buried litter within 6 hours. It has been estimated that $20 \%$ of leaf materials is lost from the mandibles on to the floor of the burrows (Camilleri, 1989). Ocypodids primarily eat bacteria (Dye \& Lasiak, 1987) or microalgae 
(France, 1998), while the consumption of leaf litter by some sesarmids has a distinct effect on litter dynamics in mangrove systems (Twilley et al., 1997; Lee, 1998). Crabs are omnivores, feeding primarily on algae (Woods, 1993) and taking any other food, including molluscs, worms, other crustaceans, fungi, bacteria and detritus, depending on their availability. For many crabs, a mixed diet of plant and animal matter results in the fastest growth and greatest fitness (Buck et al., 2003).

The most important nutrients in the coastal ecosystems are dissolved inorganic nitrogen and phosphorus compounds (Conley, 2000). According to Clough (1992), the considerable size of the root biomass of mangroves suggests they are important in nutrient cycling of organic and inorganic materials. Detritus formed the mangroves and salt marsh grasses contains high C: N and C: Pratio (Holmboe et al., 2001; Nielsen and Andersen, 2003; Silva et al., 2007). Litter fall plays a crucial role in the nutrient cycling of mangrove systems as because a large amount of organic matter returned to the aquatic system through leaf senescence. As data on litter production had already been reported from several studies (Rao et al., 1994; Lacerda et al., 1995; Mfilinge et al., 2002; Skov and Hartnoll, 2002). The abscised leaves release substantial amounts of inorganic nutrients and dissolved organic materials, which contribute sugars, proteins, and polyphenols to the surrounding water environment within a relatively short time period. Approximately $20 \%$ leaf materials after being removed from the burrows, enters the nutrient cycle as organic matter and $68 \%$ enters as ammonium (faeces) via ammonification (Camilleri, 1989). The availability of nitrogen in mangrove ecosystems depends on a complex pattern of bacterial activity within the anoxic mangrove mud, the thin oxic (oxygen-containing) zone at the visible surface of the mud, and the inner oxic linings of animal burrows. Bacteria transform nitrogen in organic materials into free ammonium, nitrate, or gaseous nitrogen through three processes: ammonification, nitrification, and denitrification. In this process of nutrient cycling, a huge amount of mangrove leaves contributed detritus are being supplied to the adjoining aquatic environment which are instrumental for the higher biological productivity in general and fishery production in particular. The considerable size of the roots and leaves of mangroves suggest that they are important in nutrient cycling of organic and inorganic materials. The intertidal belts along with mangroves function like a sponge with complex network of biogenic structures which foster to and fro movement of interstitial water, nutrients and gases both vertically and laterally coupled with tidal advection and drainage. Leaf breakdown is defined as weight loss due to physical fragmentation, animal feeding, microbial activity and leaching (Stewart \& Davies, 1989). The chemistry of mangrove detritus changes profoundly during decomposition and it involves three processes like fragmentation, leaching and decay (Robertson, 1988). The intertidal belt of the Midnapore (East) coast supports the macrobenthic fauna of which a major part of the population is being shared by the brachyuran crabs, a bio-energetically significant macrobenthic faunal group of this productive ecosystem (Chatterjee et al., 2004; Chakraborty et al., 2012; Chakraborty, 2013).

Brachyuran crabs represent an abundant faunal component in salt marshes that may have a more dominant role than other fauna due to their interactions with sediment chemistry above and belowground. Fiddler crabs are common detritivorous macrofauna of salt marshes (Bertness, 1985). The detritus that fiddler crabs consume is derived from decayed Spartina 


\section{Macrothink}

alterniflora, although their main food source is actually the microorganisms and bacteria that grow on the decomposing S. alterniflora (Genoni, 1991). Soil properties and plant assemblage characteristics influenced by crab excavation and burrow deposition can in turn affect burrowing processes (Neira et al., 2006). Sesarmid crabs play a key role as a major link between primary and secondary production through the degradation of mangrove leaf litter. The leaves of Avicennia marina contain rich nutrients more palatable compared to other mangroves leaves (Ravichandran and Kannupandi, 2004).

The present study has attempted to deal with the diversity of diets and nutritional status of gut contents (GC), excavated soil (ES) and soil surrounding burrows (SSB) in order to assess the contribution of selected brachyuran crabs in nutrient dynamics.

\section{Materials and Methods}

\subsection{Physiography of the Study Site}

The coastal tract of Midnapore (East) extends from the junction of longitudinal extension $87^{\circ}$ $20^{\prime} \mathrm{E}$ to $88^{\circ} 5^{\prime} \mathrm{E}$ and latitudinal extension $21^{\circ} 30^{\prime} \mathrm{N}$ to $22^{\circ} 2^{\prime} \mathrm{N}$. The present study has selected four sites having contrasting ecological features, viz. Talsari at extreme mouth of Subarnarekha river (S-I), Shankarpur (SII), Khejuri-Boga (SIII) and Nayachar Island (S-IV) (Figure 1).

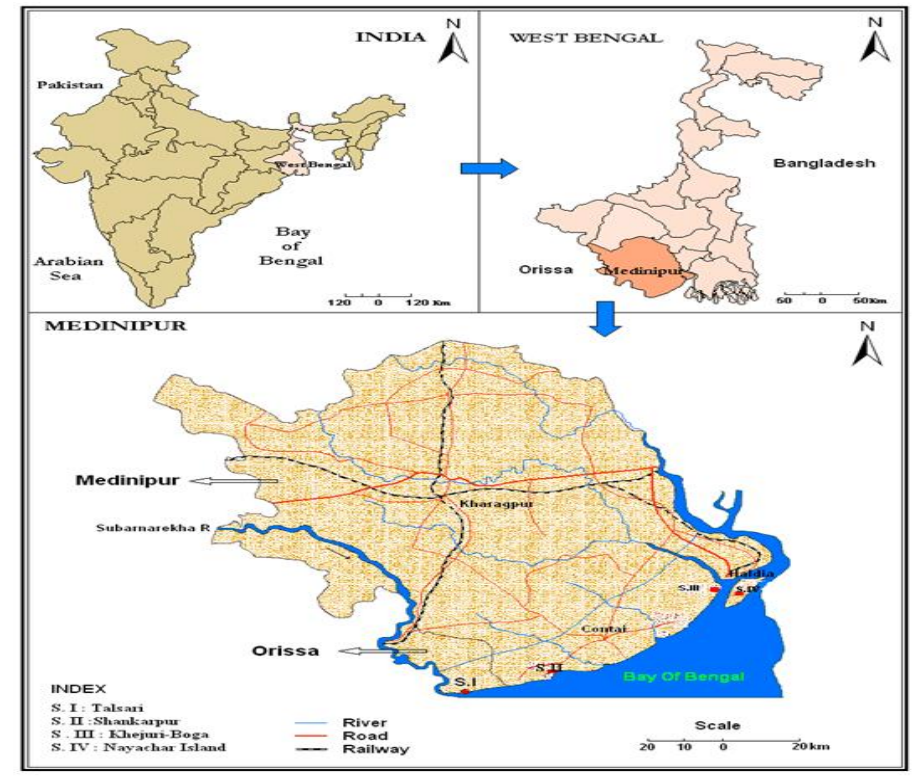

Figure 1. Map showing the different study sites

\subsection{Different Attributes of Feeding Habit and Nutrient Recycling}

For nutrient content studies, individual crabs belonging to ten different species viz. Sesarma (Chiromantes) bidens, S. taeniolatum, Metopograpsus maculatus, Metaplax intermedia and Ocypoda macrocera, Dotilla blanfordi, Dotillopsis brevitarsis, Uca acuta acuta, U. lactea annulipes, $U$. triangularis bengali were collected from their respective habitats at each season during March, 2008 to February, 2009. Within minutes of capture, crabs were injected with 
$20 \%$ formalin solution prepared in sea water and neutralized with hexamine. They were later stored in 5\% neutralized formalin and then crabs were brought back to the laboratory alive and preserved there in formalin (Malley, 1978). Soil samples were collected from the upper few centimeters of the sediment as well as crab's excavated matter from a randomly placed quadrat $(0.5 \mathrm{~m} \times 0.5 \mathrm{~m})$ were kept in plastic bags (Shin et al., 2004), and transferred to the laboratory for subsequent determination of organic carbon, available potassium, available phosphorous and available nitrogen respectively. Formalin was added to the mud samples within a few hours of collection. Gut contents of crab's community has been examined under the microscope to establish their feeding habit. The proventriculus or stomach, (cardiac and pyloric chambers) and hind gut including the rectum of preserved crab species were dissected, the gut contents were washed out and stored in $70 \%$ ethanol. To assess the role of different crabs on nutrient recycle, gut contents including stomach (cardiac and pyloric chambers) and abdominal hindgut including the rectum of preserved crabs, excavated soil were analyzed under a dissecting microscope at 40X magnification and measured as well as compared different nutrients levels from the gut content, excavated soil and soil surrounding burrows of their habitat. Identification and measurement of particles from the gut samples were carried out under microscope in terms of percentage.

\subsection{Statistical Analyses}

Different statistical analyses were done by following standard books (Zar, 2009) and utilizing 'STATISTICA' (STATSOFT, 2001) and 'SPSS (10.0)' packages with the help of a P-4 computer. Diet diversity study was performed following Chi square test to test the independence of attributes between season and species using the frequency data of accepting a specific diet. Such analysis was repeated for each type of diet. Factorial ANOVA technique was used to compare the main effects of species and season for each type of nutrition on gut contents (GC), excavated soils (ES) and soils surrounding burrows (SSB). Main effects of means were further subjected to Duncan's test at 5\% level of significance to test the homogeneity among respective means for each factor. Significance of all main and interaction effects were also tested by $\mathrm{F}$ tests at each ANOVA. Significant main effects for factors having more than two levels were subjected to Duncan's test. Here, similar alphabets denote homogenous means at $5 \%$ level of significance.

\section{Results}

The gut content materials (in the proventriculus and rectum), after initial observation was divided into two categories: i)Broken part of mangrove leaf, mesophyll tissue, degraded leaf particles, different algae, animal parts and ii) Unidentified materials mostly composed of soil fine molecules (sand, silt). The gut content materials present in the provenentriculas of studied species of crabs have revealed food items in the diet and they were compared with those of the rectum and abdominal portion of the hind gut to observe the degree of digestion by the crabs. Gut content compositions also displayed their feeding habit and behaviour (Table 1).

Table1. Diet diversity of different selected brachyuran crabs (in terms of \%) in different seasons during March'2008-Feburay'2009 


\begin{tabular}{|c|c|c|c|c|c|c|c|}
\hline \multirow{2}{*}{ Seasons } & \multirow{2}{*}{ Species } & \multicolumn{6}{|c|}{ Diet diversity } \\
\hline & & Ml & Dlp & $\mathrm{Da}$ & Ap & $\mathrm{D}$ & Um \\
\hline \multicolumn{8}{|c|}{ Family: Grapsidae } \\
\hline \multirow{3}{*}{$\begin{array}{c}\text { PRM,08 } \\
\text { MON,08 } \\
\text { POM,08-09 }\end{array}$} & \multirow{3}{*}{ Sesarma (Chiromantes) bidens } & 82 & 8 & 4 & 0 & 2 & 4 \\
\hline & & 80 & 6 & 6 & 0 & 3 & 5 \\
\hline & & 90 & 8 & 2 & 0 & 0 & 0 \\
\hline \multirow{3}{*}{$\begin{array}{c}\text { PRM,08 } \\
\text { MON,08 } \\
\text { POM,08-09 }\end{array}$} & \multirow{3}{*}{ Sesarma taeniolatum } & 80 & 11 & 3 & 0 & 3 & 3 \\
\hline & & 77 & 10 & 5 & 0 & 2 & 6 \\
\hline & & 84 & 6 & 4 & 0 & 1 & 5 \\
\hline \multirow{3}{*}{$\begin{array}{c}\text { PRM,08 } \\
\text { MON,08 } \\
\text { POM,08-09 }\end{array}$} & \multirow{3}{*}{ Metopograpsus maculatus } & 78 & 12 & 6 & 0 & 2 & 2 \\
\hline & & 82 & 6 & 7 & 0 & 4 & 1 \\
\hline & & 86 & 4 & 3 & 0 & 3 & 4 \\
\hline \multirow{3}{*}{$\begin{array}{c}\text { PRM,08 } \\
\text { MON,08 } \\
\text { POM,08-09 }\end{array}$} & \multirow{3}{*}{ Metaplax intermedia } & 0 & 0 & 18 & 6 & 64 & 12 \\
\hline & & 0 & 0 & 22 & 8 & 60 & 10 \\
\hline & & 0 & 0 & 14 & 11 & 72 & 3 \\
\hline \multicolumn{8}{|c|}{ Family: Ocypodidae } \\
\hline \multirow{3}{*}{$\begin{array}{c}\text { PRM,08 } \\
\text { MON,08 } \\
\text { POM,08-09 }\end{array}$} & \multirow{3}{*}{ Uca acuta acuta } & 0 & 1 & 15 & 4 & 70 & 10 \\
\hline & & 0 & 0 & 18 & 6 & 74 & 2 \\
\hline & & 0 & 0 & 17 & 4 & 68 & 11 \\
\hline \multirow{3}{*}{$\begin{array}{c}\text { PRM,08 } \\
\text { MON,08 } \\
\text { POM,08-09 }\end{array}$} & \multirow{3}{*}{ Uca lactea annulipes } & 0 & 0 & 18 & 4 & 66 & 12 \\
\hline & & 0 & 0 & 22 & 3 & 71 & 4 \\
\hline & & 0 & 0 & 16 & 0 & 80 & 4 \\
\hline \multirow{3}{*}{$\begin{array}{c}\text { PRM,08 } \\
\text { MON,08 } \\
\text { POM,08-09 }\end{array}$} & \multirow{3}{*}{ Uca triangularis bengali } & 0 & 0 & 26 & 5 & 55 & 14 \\
\hline & & 0 & 0 & 16 & 2 & 70 & 12 \\
\hline & & 0 & 0 & 11 & 0 & 68 & 21 \\
\hline \multirow{3}{*}{$\begin{array}{c}\text { PRM,08 } \\
\text { MON,08 } \\
\text { POM,08-09 }\end{array}$} & \multirow{3}{*}{ Ocypoda macrocera } & 0 & 0 & 4 & 64 & 14 & 18 \\
\hline & & 0 & 0 & 11 & 71 & 8 & 10 \\
\hline & & 0 & 0 & 8 & 79 & 10 & 3 \\
\hline \multirow{3}{*}{$\begin{array}{c}\text { PRM,08 } \\
\text { MON,08 } \\
\text { POM,08-09 }\end{array}$} & \multirow{3}{*}{ Dotilla blanfordi } & 0 & 0 & 7 & 25 & 49 & 19 \\
\hline & & 0 & 0 & 8 & 22 & 57 & 13 \\
\hline & & 0 & 0 & 4 & 12 & 77 & 7 \\
\hline \multirow{3}{*}{$\begin{array}{c}\text { PRM,08 } \\
\text { MON,08 } \\
\text { POM,08-09 }\end{array}$} & \multirow{3}{*}{ Dotillopsis brevitarsis } & 0 & 0 & 5 & 11 & 56 & 28 \\
\hline & & 0 & 0 & 7 & 9 & 61 & 23 \\
\hline & & 0 & 0 & 9 & 7 & 66 & 18 \\
\hline
\end{tabular}

$\mathrm{Ml}=$ Mangrove leaf, Dlp=Degraded leaf particles, $\mathrm{Da}=$ Different algae $\mathrm{Ap}=\mathrm{Animal}$ parts, $\mathrm{D}=\mathrm{Detritus}$, $\mathrm{Um}=$ Unidentified materials (sand, silt), $\mathrm{PRM}=$ Pre-monsoon, $\mathrm{Mon}=$ Monsoon, $\mathrm{POM}=$ Post-monsoon

The diet of M. maculatus, S. taeniolatum and S. (Chiromantes) bidens consisted mainly of plant materials i.e. mangrove leaves showed very low diversity of diet. The most important food component of $M$. maculatus was mangrove leaves particularly Avicennia officinalis and A. marina, whereas, Acanthus ilicifolius was found to be present in the stomachs of $S$. 


\section{$\triangle 1$ Macrothink}

Journal of Biology and Life Science ISSN 2157-6076 2014, Vol. 5, No. 1

(Chiromantes) bidens and S. taeniolatum. Sediment constituted significant sources of food other than plant materials in $O$. macrocera, D. blanfordi and D. brevitarsis and the gut content analyses exhibited that the diet of $O$. macrocera, D. blanfordi and D. brevitarsis consisted mainly of sand particles and to some extent animal parts. Sediments intake is probably very significant to these crabs. Animal materials consisted of small pieces of polychaetes, mollusks and other unidentified animal structures. Maximum animal part was seen in both chambers of stomach (cardiac and pyloric) and hind gut of O. macrocera. D. blanfordi and D. brevitarsis which were exclusively deposit feeders and omnivores due to the maximum occurrence of sand particles, algae and detritus. The gut contents of fiddler crabs viz. U. acuta acuta, U. lactea annulipes, $U$. triangularis bengali and $M$. intermedia have revealed the presence of algal complex, detritus and mud particles in the diet.

Analyses were completed seasonally by the determination of the organic carbon, available phosphorus, available potassium and available nitrogen from GC, ES and SSB. Nutritional values in the form of organic carbon $(\%)$, available phosphorus (mg/100gm), available potassium $(\mathrm{mg} / 100 \mathrm{gm})$ and available nitrogen $(\mathrm{mg} / 100 \mathrm{gm})$ during pre-monsoon, 2008, monsoon, 2008 and post-monsoon, 2008-2009 has been shown in Tables 2 to 4 .

Table 2. Nutritional status of gut contents (GC), excavated soil (ES) and soil surrounding burrows (SSB) of different selected brachyuran crabs during pre-monsoon, 2008

\begin{tabular}{|c|c|c|c|c|c|c|c|c|c|c|c|c|}
\hline \multirow{2}{*}{$\begin{array}{c}\text { Different } \\
\text { Brachyurans }\end{array}$} & \multicolumn{3}{|c|}{$\begin{array}{c}\text { Organic carbon } \\
(\%)\end{array}$} & \multicolumn{3}{|c|}{$\begin{array}{l}\text { Available phosphorus } \\
\text { (mg/100gm) }\end{array}$} & \multicolumn{3}{|c|}{$\begin{array}{c}\text { Available potassium } \\
\text { (mg/100gm) }\end{array}$} & \multicolumn{3}{|c|}{$\begin{array}{l}\text { Available Nitrogen } \\
(\mathrm{mg} / 100 \mathrm{gm})\end{array}$} \\
\hline & GC & ES & SSB & $\mathrm{GC}$ & $\mathrm{ES}$ & SSB & $\mathrm{GC}$ & ES & SSB & GC & ES & SSB \\
\hline M. maculatus & 1.40 & 1.24 & 0.78 & 3.22 & 2.28 & 1.24 & 0.72 & 0.47 & 0.26 & 10.24 & 13.42 & 7.84 \\
\hline $\begin{array}{c}S . \\
\text { (Chiromantes) } \\
\text { bidens }\end{array}$ & 2.80 & 1.66 & 1.07 & 2.24 & 1.86 & 3.25 & 0.33 & 0.25 & 0.68 & 7.26 & 8.22 & 9.22 \\
\hline S.taeniolatum & 2.14 & 1.21 & 0.89 & 1.89 & 1.34 & 3.21 & 0.28 & 0.29 & 0.48 & 5.33 & 7.12 & 7.24 \\
\hline M. intermedia & 0.69 & 0.42 & 0.44 & 0.64 & 1.24 & 1.30 & 0.58 & 0.74 & 0.44 & 3.23 & 6.26 & 4.24 \\
\hline O. macrocera & 0.48 & 0.18 & 0.25 & 0.68 & 1.16 & 1.05 & 1.04 & 0.78 & 0.47 & 2.44 & 8.24 & 3.22 \\
\hline D. blanfordi & 0.33 & 0.04 & 0.23 & 0.32 & 1.01 & 0.89 & 0.46 & 0.54 & 0.58 & 1.04 & 2.24 & 2.12 \\
\hline D. brevitarsis & 0.06 & 0.22 & 0.12 & 0.45 & 2.10 & 1.48 & 0.64 & 0.47 & 0.32 & 1.08 & 5.47 & 4.28 \\
\hline U. acuta acuta & 0.74 & 0.84 & 0.45 & 0.94 & 1.84 & 1.05 & 0.64 & 0.58 & 0.32 & 5.40 & 10.47 & 5.24 \\
\hline $\begin{array}{l}\text { U. lactea } \\
\text { annulipes }\end{array}$ & 0.89 & 0.66 & 0.54 & 1.64 & 2.83 & 1.33 & 0.60 & 0.80 & 0.49 & 5.82 & 9.78 & 7.45 \\
\hline $\begin{array}{c}\text { U. triangularis } \\
\text { bengali }\end{array}$ & 0.82 & 0.24 & 0.74 & 1.67 & 2.05 & 1.11 & 0.28 & 0.49 & 0.34 & 5.23 & 11.72 & 3.21 \\
\hline
\end{tabular}

Table 3. Nutritional status of gut contents (GC), excavated soil (ES) and soil surrounding burrows (SSB) of different selected brachyuran crabs during monsoon, 2008

\begin{tabular}{|l|l|l|l|l|} 
Different & Organic carbon & Available phosphorus & Available potassium & Available Nitrogen \\
\hline
\end{tabular}




\section{MInstitute Macrothink}

Journal of Biology and Life Science

ISSN 2157-6076

2014, Vol. 5, No. 1

\begin{tabular}{|c|c|c|c|c|c|c|c|c|c|c|c|c|}
\hline \multirow{2}{*}{ Brachyurans } & \multicolumn{3}{|c|}{$(\%)$} & \multicolumn{3}{c|}{$(\mathrm{mg} / 100 \mathrm{gm})$} & \multicolumn{3}{c|}{$(\mathrm{mg} / 100 \mathrm{gm})$} & \multicolumn{3}{c|}{$(\mathrm{mg} / 100 \mathrm{gm})$} \\
\cline { 2 - 13 } & GC & $\mathrm{ES}$ & $\mathrm{SSB}$ & $\mathrm{GC}$ & $\mathrm{ES}$ & $\mathrm{SSB}$ & GC & ES & SSB & GC & ES & SSB \\
\hline M. maculatus & 1.12 & 1.04 & 1.34 & 2.24 & 2.08 & 0.84 & 0.68 & 0.40 & 0.24 & 8.24 & 10.35 & 5.58 \\
\hline $\begin{array}{c}\text { S. } \\
\text { (Chiromantes) } \\
\text { bidens }\end{array}$ & 2.24 & 1.35 & 0.89 & 1.04 & 0.89 & 2.24 & 0.44 & 0.24 & 0.48 & 8.24 & 6.48 & 5.58 \\
\hline S.taeniolatum & 1.89 & 1.20 & 1.21 & 0.98 & 0.54 & 1.79 & 0.53 & 0.32 & 0.27 & 8.62 & 5.78 & 4.87 \\
\hline M. intermedia & 0.22 & 0.22 & 0.34 & 0.54 & 0.76 & 0.66 & 0.35 & 0.55 & 0.55 & 3.54 & 5.55 & 4.48 \\
\hline O. macrocera & 0.25 & 0.06 & 0.16 & 0.46 & 0.88 & 0.65 & 0.84 & 0.58 & 0.35 & 1.68 & 6.42 & 3.06 \\
\hline D. blanfordi & 0.00 & 0.04 & 0.08 & 0.20 & 0.85 & 0.82 & 0.33 & 0.44 & 0.56 & 1.22 & 1.84 & 2.08 \\
\hline D. brevitarsis & 0.02 & 0.04 & 0.22 & 0.64 & 1.84 & 1.40 & 0.40 & 0.45 & 0.56 & 1.14 & 3.42 & 4.80 \\
\hline U. acuta acuta & 0.66 & 0.74 & 0.64 & 1.04 & 2.14 & 1.24 & 0.42 & 0.52 & 0.22 & 4.50 & 9.44 & 6.40 \\
\hline $\begin{array}{c}\text { U. lactea } \\
\text { annulipes }\end{array}$ & 0.75 & 0.54 & 0.48 & 1.42 & 1.84 & 1.46 & 0.55 & 1.08 & 1.08 & 3.45 & 6.40 & 5.45 \\
\hline $\begin{array}{c}\text { U. triangularis } \\
\text { bengali }\end{array}$ & 0.86 & 0.54 & 1.01 & 1.67 & 2.05 & 1.11 & 0.16 & 0.79 & 0.99 & 5.23 & 11.72 & 3.21 \\
\hline
\end{tabular}

Table 4. Nutritional status of gut contents (GC), excavated soil (ES) and soil surrounding burrows (SSB) of different selected brachyuran crabs during post monsoon, 2008-2009

\begin{tabular}{|c|c|c|c|c|c|c|c|c|c|c|c|c|}
\hline \multirow{2}{*}{$\begin{array}{c}\text { Different } \\
\text { Brachyurans }\end{array}$} & \multicolumn{3}{|c|}{$\begin{array}{c}\text { Organic carbon } \\
(\%)\end{array}$} & \multicolumn{3}{|c|}{$\begin{array}{l}\text { Available phosphorus } \\
\text { (mg/100gm) }\end{array}$} & \multicolumn{3}{|c|}{$\begin{array}{l}\text { Available potassium } \\
(\mathrm{mg} / 100 \mathrm{gm})\end{array}$} & \multicolumn{3}{|c|}{$\begin{array}{l}\text { Available Nitrogen } \\
(\mathrm{mg} / 100 \mathrm{gm})\end{array}$} \\
\hline & GC & ES & SSB & GC & ES & SSB & GC & ES & SSB & GC & ES & SSB \\
\hline M. maculatus & 1.66 & 2.2 & 2.2 & 3.45 & 4.28 & 2.46 & 0.68 & 0.85 & 1.25 & 4.44 & 11.2 & 11.48 \\
\hline $\begin{array}{c}S . \\
\text { (Chiromantes) } \\
\text { bidens }\end{array}$ & 1.58 & 1.88 & 2.10 & 2.54 & 2.24 & 2.20 & 1.20 & 1.48 & 1.55 & 7.48 & 8.42 & 12.24 \\
\hline S.taeniolatum & 1.50 & 1.46 & 2.17 & 2.20 & 1.79 & 1.89 & 1.08 & 1.34 & 1.24 & 6.44 & 8.69 & 12.74 \\
\hline M. intermedia & 2.45 & 2.65 & 2.85 & 1.2 & 1.28 & 1.45 & 1.20 & 1.48 & 1.85 & 4.20 & 6.55 & 4.48 \\
\hline O. macrocera & 0.25 & 0.06 & 0.16 & 0.46 & 0.88 & 0.65 & 0.84 & 0.58 & 0.35 & 2.24 & 7.45 & 4.45 \\
\hline D. blanfordi & 0.00 & 0.07 & 0.08 & 0.28 & 0.94 & 0.92 & 0.44 & 0.64 & 0.76 & 2.20 & 4.60 & 3.25 \\
\hline D. brevitarsis & 0.03 & 0.08 & 0.72 & 0.54 & 2.25 & 3.24 & 0.48 & 0.65 & 0.72 & 2.20 & 3.48 & 5.24 \\
\hline U. acuta acuta & 0.68 & 0.82 & 0.70 & 1.54 & 2.60 & 2.40 & 0.72 & 0.75 & 0.85 & 3.45 & 7.2 & 5.25 \\
\hline $\begin{array}{l}\text { U. lactea } \\
\text { annulipes }\end{array}$ & 0.70 & 0.62 & 0.55 & 1.55 & 1.95 & 1.60 & 0.75 & 1.24 & 1.05 & 4.50 & 6.80 & 6.35 \\
\hline $\begin{array}{l}\text { U. triangularis } \\
\text { bengali }\end{array}$ & 0.48 & 0.14 & 0.24 & 1.08 & 1.20 & 1.55 & 0.58 & 0.65 & 0.64 & 2.68 & 8.82 & 10.25 \\
\hline
\end{tabular}

Statistical evaluation of nutritional status from GC, ES and SSB through Chi square test, ANOVA analysis and Duncan's test of different species has been shown in Tables 5 to 7 .

Table 5. Chi square test of independence of attributes to study the effect of season on mangrove 
leaf, degraded leaf particles, different algae, animal part, detritus and unidentified materials dependant species

\begin{tabular}{|c|c|c|c|}
\hline & Value & $\mathrm{df}$ & Asymp. Sig. (2-sided) \\
\hline \multicolumn{4}{|c|}{ Ml } \\
\hline Pearson Chi-Square & $.228^{\mathrm{a}}$ & 4 & 0.994 \\
\hline Likelihood Ratio & 0.228 & 4 & 0.994 \\
\hline $\mathrm{N}$ of Valid Cases & 739 & & \\
\hline \multicolumn{4}{|c|}{ a. 0 cells $(.0 \%)$ have expected count less than 5 . The minimum expected count is 77.94 . } \\
\hline \multicolumn{4}{|c|}{ Dlp } \\
\hline Pearson Chi-Square & $3.036^{\mathrm{a}}$ & 4 & 0.552 \\
\hline Likelihood Ratio & 2.926 & 4 & 0.57 \\
\hline $\mathrm{N}$ of Valid Cases & 71 & & \\
\hline \multicolumn{4}{|c|}{ a. $\quad 0$ cells $(.0 \%)$ have expected count less than 5 . The minimum expected count is 5.58 . } \\
\hline \multicolumn{4}{|c|}{ Da } \\
\hline Pearson Chi-Square & $14.468^{\mathrm{a}}$ & 18 & 0.698 \\
\hline Likelihood Ratio & 14.434 & 18 & 0.7 \\
\hline $\mathrm{N}$ of Valid Cases & 316 & & \\
\hline \multicolumn{4}{|c|}{ a. 7 cells $(23.3 \%)$ have expected count less than 5 . The minimum expected count is 3.34 . } \\
\hline \multicolumn{4}{|c|}{ Ap } \\
\hline Pearson Chi-Square & $18.412^{\mathrm{a}}$ & 12 & 0.104 \\
\hline Likelihood Ratio & 22.14 & 12 & $.036 *$ \\
\hline $\mathrm{N}$ of Valid Cases & 353 & & \\
\hline \multicolumn{4}{|c|}{$\begin{array}{c}\text { a. } 9 \text { cells }(42.9 \%) \text { have expected count less than } 5 \text {. The minimum expected count is } 2.24 \text {. } \\
* \text { significant at the } 0.05 \text { level } * * \text { significant at the } 0.01 \text { level }\end{array}$} \\
\hline \multicolumn{4}{|c|}{$\mathrm{D}$} \\
\hline Pearson Chi-Square & $13.657^{\mathrm{a}}$ & 18 & 0.751 \\
\hline Likelihood Ratio & 15.11 & 18 & 0.654 \\
\hline $\mathrm{N}$ of Valid Cases & 1236 & & \\
\hline \multicolumn{4}{|c|}{ a. 9 cells $(30.0 \%)$ have expected count less than 5 . The minimum expected count is 1.54 . } \\
\hline \multicolumn{4}{|c|}{$\mathrm{Um}$} \\
\hline Pearson Chi-Square & $37.849^{\mathrm{a}}$ & 18 & 0.004 \\
\hline Likelihood Ratio & 41.159 & 18 & $.001 * *$ \\
\hline $\mathrm{N}$ of Valid Cases & 284 & & \\
\hline $\begin{array}{r}8 \text { cells }(26.7 \%) \text { have } \\
* \text { significa }\end{array}$ & $\begin{array}{l}\mathrm{d} \text { count les } \\
0.05 \text { level }\end{array}$ & $\begin{array}{l}\text { In } 5 . \\
\text { ignif }\end{array}$ & $\begin{array}{l}\text { imum expected count is } 1.87 \text {. } \\
\text { he } 0.01 \text { level }\end{array}$ \\
\hline
\end{tabular}

\subsection{Results of Chi Square Test}

From the Chi square test (Table 5), it was noticed that the effect of seasons on the diet of $S$. (Chiromantes) bidens, S. taeniolatum and M. maculatus to eat mangrove leaf (Ml), degraded leaf particles (Dlp) as food was not significant; in S. (Chiromantes) bidens, S. taeniolatum, $M$. 
maculatus, U. acuta acuta, U. lactea annulipes, $U$. triangularis bengali, D. blanfordi and $D$. brevitarsis to eat different algae (Da) as food was not significant; in D. blanfordi, D. brevitarsis, $M$. intermedia, O. macrocera, U. acuta acuta, U. lactea annulipes and U. triangularis bengali to eat animal parts (Ap) as food was significant at 5\%; all the studied species to eat detritus (D) as food was not significant and unidentified materials (Um) as food was significant at $1 \%$ level of significance.

\subsection{Results of ANOVA Analysis and Duncan's Test}

ANOVA analysis showed that organic carbon, available phosphorus and available nitrogen within the GC, ES and SSB had significant main effects along with the species excepting available potassium. On the other hand, available potassium within the GC, ES and SSB had significant key effects along with seasons; available nitrogen within the ES and SSB had significant main effects along with seasons; available phosphorus within the GC had significant major effects along with seasons and organic carbon within the SSB had significant effects along with seasons (Table 6).

Regarding the main effects of species on different nutritional contents when compared by Duncan's test at 5\% level of significance (Table 7), it became evident that the mean of organic carbon within GC of $S$. (Chiromantes) bidens, was significant than the means of all species except $S$. taeniolatum and $M$. maculatus. In $S$. taeniolatum, mean of organic carbon within GC was significant difference than the means of all species except $M$. maculatus and $M$. intermedia. In M. maculatus, mean of organic carbon within GC was significantly higher difference than the means of $O$. macrocera, D. blanfordi and D. brevitarsis. In M. intermedia, mean of organic carbon was significant than the mean of $D$. blanfordi and D. brevitarsis. But the means organic carbon of $U$. lactea annulipes, $U$. triangularis bengali, $U$. acuta acuta, $O$. macrocera, D. blanfordi and D. brevitarsis were all homogenous. The mean of organic carbon within ES of $S$. (Chiromantes) bidens, M. maculatus, S. taeniolatum, M. intermedia and $U$. acuta acuta were all homogeneous. In S. (Chiromantes) bidens and M. maculatus, means were significant than the means of $U$. lactea annulipes, $U$. triangularis bengali, D. brevitarsis, $O$. macrocera and D. blanfordi. In S. taeniolatum, mean was significant than the means of $U$. triangularis bengali, D. brevitarsis, O. macrocera and D. blanfordi. In M. intermedia, mean was significantly higher difference than the means of $D$. brevitarsis, $O$. macrocera and $D$. blanfordi. But mean of organic carbon of $U$. acuta acuta, U. lactea annulipes, $U$. triangularis bengali, D. brevitarsis, O. macrocera and D. blanfordi were all homogenous. The mean of organic carbon within SSB of $M$. maculatus and S. taeniolatum were significant than the means of $D$. brevitarsis, O. macrocera and D. blanfordi. Again the means of $S$. (Chiromantes) bidens and $M$. intermedia were significant than the means of $O$. macrocera and D. blanfordi. But means of $U$. triangularis bengali, $U$. acuta acuta, $U$. lactea annulipes, D. brevitarsis, $O$. macrocera and D. blanfordi were all homogeneous. In Duncan's $(\mathrm{P}=0.05)$ test, the mean of available phosphorus within GC of $M$. maculatus was significant than the means of all species. In $S$. (Chiromantes) bidens, mean of available phosphorus was significant than means of $U$. acuta acuta, M. intermedia, D. brevitarsis, O. macrocera and D. blanfordi. The means of available phosphorus of $S$. taeniolatum, $U$. lactea annulipes and $U$. triangularis bengali were significant than the means $M$. intermedia, D. brevitarsis, O. macrocera and D. blanfordi. But 
the mean of available phosphorus of $D$. blanfordi was significantly less difference than all species except the means of $O$. macrocera, D. brevitarsis and $M$. intermedia. The mean of available phosphorus within ES of M. maculatus, was significant than the means of $U$. triangularis bengali, $S$. (Chiromantes) bidens, S. taeniolatum, M. intermedia, O. macrocera and D. blanfordi. In $U$. lactea annulipes and $U$. acuta acuta, means of available phosphorus were significant than the means of $M$. intermedia, O. macrocera and D. blanfordi. In $D$. brevitarsis, mean of available phosphorus was significant than the means of $O$. macrocera and D. blanfordi. But means of available phosphorus of $U$. triangularis bengali, $S$. (Chiromantes) bidens, S. taeniolatum, M. intermedia, O. macrocera and D. blanfordi were all homogeneous. The mean of available phosphorus within SSB of $S$. (Chiromantes) bidens, was significant than the means of $M$. maculatus, $U$. lactea annulipes, $U$. triangularis bengali, $M$. intermedia, $D$. blanfordi and $O$. macrocera. In $S$. taeniolatum, mean was significant than the means of $M$. intermedia, D. blanfordi and O. macrocera. In D. brevitarsis mean of available phosphorus was significantly higher difference than the means of $O$. macrocera and D. blanfordi. But the means of available phosphorus of $U$. acuta acuta, M. maculatus, U. lactea annulipes, $U$. triangularis bengali, D. blanfordi and O. macrocera were all homogeneous. Concerning the main effects of species due to different nutritional contents when compared by Duncan's test at $5 \%$ level of significance, it was made clear that, the mean of available potassium within GC of O. macrocera, was significant than the means $U$. triangularis bengali and D. blanfordi only. The mean of available potassium within ES and SSB in all studied species was all homogeneous. In Duncan's test, the mean of available nitrogen within GC of $S$. (Chiromantes) bidens and M. maculatus was significant than the means of U. lactea annulipes, U. acuta acuta, $U$. triangularis bengali, $M$. intermedia, O. macrocera, D. blanfordi and D. brevitarsis. In $S$. taeniolatum mean of available nitrogen was significant than the means of $M$. intermedia, $O$. macrocera, D. blanfordi and D. brevitarsis. In $U$. lactea annulipes, $U$. acuta acuta and $U$. triangularis bengali, the means were significantly higher difference than $D$. blanfordi and $D$. brevitarsis. But the means of available nitrogen of $M$. intermedia, O. macrocera, D. blanfordi and $D$. brevitarsis were all homogeneous. The mean of available nitrogen within ES of $M$. maculatus was significant than all species' means except $U$. triangularis bengali. Again the mean of available nitrogen of $U$. triangularis bengali, was significant than means of all remaining species except $U$. acuta acuta. In $U$. acuta acuta, the mean was significantly higher difference than the means of $M$. intermedia, D. brevitarsis and $D$. blanfordi only. In $S$. (Chiromantes) bidens, U. lactea annulipes, O. macrocera, S. taeniolatum, the means were significant than the means of $D$. brevitarsis and D. blanfordi only. In M. intermedia, the mean of available nitrogen was significant than the mean of $D$. blanfordi only. But the means of available nitrogen of $D$. brevitarsis and $D$. blanfordi were homogeneous. The mean of available nitrogen within SSB of $S$. (Chiromantes) bidens was significant than means of $D$. brevitarsis, $M$. intermedia, O. macrocera and D. blanfordi. In S. taeniolatum and M. maculatus, the means were significant than the means of $M$. intermedia, O. macrocera and D. blanfordi. In $U$. lactea annulipes, the mean was significant than the mean of $D$. blanfordi only. In $D$. blanfordi, the mean was significantly less difference than the means of $U$. lactea annulipes, $M$. maculatus, S. taeniolatum and $S$. (Chiromantes) bidens only respectively.

Duncan's test $(\mathrm{P}=0.05)$ with respect to the main effects of seasons, on different nutritional 
contents, revealed that the mean of organic carbon with in GC and ES displayed no significant differences during different seasons but within SSB, it showed significant differences during post-monsoon, 2008-2009 than pre-monsoon, 2008 and monsoon, 2008. The mean of available phosphorus within GC, ES and SSB was significant during post-monsoon, 2008-2009 than monsoon, 2008. The mean of available potassium within GC, ES and SSB was recorded significantly higher difference during post-monsoon, 2008-2009 than monsoon, 2008 and pre-monsoon, 2008. In available nitrogen within GC, it displayed no significant variation during different seasons; within ES, it was found significant during pre-monsoon, 2008 than monsoon, 2008, and within SSB exhibited significantly higher difference during post-monsoon, 2008-2009 than pre-monsoon, 2008 and monsoon, 2008 respectively.

Table 6. Results of ANOVA analysis of different nutritional quantity of gut contents (GC), excavated soil (ES) and soils surrounding burrows (SSB) between species and seasons

\begin{tabular}{|c|c|c|c|c|c|c|c|c|c|c|c|}
\hline \multicolumn{2}{|c|}{ ANOVA } & \multicolumn{5}{|c|}{ Organic carbon $(\%)$} & \multicolumn{5}{|c|}{ Available phosphorus (mg/gm) } \\
\hline Source & Variables & SS & $\mathrm{df}$ & MS & $\mathrm{F}$ & Sig. & SS & $\mathrm{df}$ & MS & $\mathrm{F}$ & Sig. \\
\hline Different & GC & 14.01 & 9 & 1.56 & 7.36 & $0.000 * *$ & 17.81 & 9 & 1.98 & 14.18 & $0.000^{* * *}$ \\
\hline \multirow{2}{*}{$\begin{array}{c}\text { Brachyurans } \\
\text { species }\end{array}$} & ES & 9.83 & 9 & 1.09 & 5.25 & $0.001 * *$ & 11.22 & 9 & 1.25 & 4.67 & $0.003 * *$ \\
\hline & BSS & 7.28 & 9 & 0.81 & 2.87 & $0.027^{*}$ & 9.4 & 9 & 1.04 & 3.52 & $0.011 *$ \\
\hline & & \multicolumn{5}{|c|}{ Available potassium (mg/gm) } & \multicolumn{5}{|c|}{ Available nitrogen $(\mathrm{mg} / \mathrm{gm})$} \\
\hline Different & GC & 0.7 & 9 & 0.08 & 1.68 & 0.166 & 149.12 & 9 & 16.57 & 9.34 & $0.000^{* *}$ \\
\hline Brachyurans & ES & 0.76 & 9 & 0.08 & 1.11 & 0.402 & 194.72 & 9 & 21.64 & 14.6 & $0.000 * *$ \\
\hline species & BSS & 0.96 & 9 & 0.11 & 1.05 & 0.444 & 124.72 & 9 & 13.86 & 3.98 & $0.006^{* *}$ \\
\hline \multirow{3}{*}{ Seasons } & GC & 0.28 & 2 & 0.14 & 0.65 & 0.533 & 1.15 & 2 & 0.58 & 4.13 & $0.034 *$ \\
\hline & ES & 0.98 & 2 & 0.49 & 2.35 & 0.124 & 1.61 & 2 & 0.81 & 3.02 & 0.074 \\
\hline & SSB & 2.3 & 2 & 1.15 & 4.09 & $0.034 *$ & 1.92 & 2 & 0.96 & 3.24 & 0.063 \\
\hline \multirow{3}{*}{ Seasons } & GC & 0.57 & 2 & 0.29 & 6.24 & $0.009 * *$ & 3.01 & 2 & 1.5 & 0.85 & 0.445 \\
\hline & ES & 1.22 & 2 & 0.61 & 8.05 & $0.003 * *$ & 12.33 & 2 & 6.17 & 4.17 & $0.032 *$ \\
\hline & SSB & 2 & 2 & 1 & 9.78 & $0.001 * *$ & 48.86 & 2 & 24.43 & 7.02 & $0.006^{* * *}$ \\
\hline \multirow{3}{*}{ Error } & GC & 3.81 & 18 & 0.21 & & & 2.51 & 18 & 0.14 & & \\
\hline & ES & 3.75 & 18 & 0.21 & & & 4.8 & 18 & 0.27 & & \\
\hline & SSB & 5.07 & 18 & 0.28 & & & 5.33 & 18 & 0.3 & & \\
\hline \multirow{3}{*}{ Error } & GC & 0.83 & 18 & 0.05 & & & 31.92 & 18 & 1.77 & & \\
\hline & ES & 1.36 & 18 & 0.08 & & & 26.6 & 18 & 1.48 & & \\
\hline & SSB & 1.84 & 18 & 0.1 & & & 62.61 & 18 & 3.48 & & \\
\hline \multirow{3}{*}{ Total } & GC & 18.1 & 29 & & & & 21.48 & 29 & & & \\
\hline & ES & 14.55 & 29 & & & & 17.64 & 29 & & & \\
\hline & SSB & 14.66 & 29 & & & & 16.64 & 29 & & & \\
\hline \multirow{3}{*}{ Total } & GC & 2.1 & 29 & & & & 184.04 & 29 & & & \\
\hline & ES & 3.33 & 29 & & & & 233.65 & 29 & & & \\
\hline & SSB & 4.81 & 29 & & & & 236.18 & 29 & & & \\
\hline
\end{tabular}

$\mathrm{SS}=$ sums of squares, $\mathrm{df}=$ degrees of freedom, $\mathrm{MS}=\mathrm{SS} / \mathrm{df}, \mathrm{F}=\mathrm{MS}$ group/MS within group

* Significant at the 0.05 level $* *$ Significant at the 0.01 level

Table 7. The mean effect of different nutritional quantity of gut contents (GC), excavated soil 
(ES) and soils surrounding burrows (SSB) between species and seasons with Duncan's test results

\begin{tabular}{|c|c|c|c|c|c|c|c|}
\hline \multirow[t]{2}{*}{ Species } & \multirow[t]{2}{*}{ Seasons } & \multicolumn{3}{|c|}{$\begin{array}{c}\text { Organic Carbon } \\
(\%) \\
\end{array}$} & \multicolumn{3}{|c|}{$\begin{array}{l}\text { Available Phosphorus } \\
\qquad(\mathrm{mg} / \mathrm{gm})\end{array}$} \\
\hline & & $\mathrm{GC}$ & ES & SSB & $\mathrm{GC}$ & ES & SSB \\
\hline \multirow{9}{*}{ S.(Chiromantes) bidens } & Total & $2.21 \mathrm{p}$ & $1.63 p$ & $1.35 \mathrm{pq}$ & $1.94 \mathrm{q}$ & $1.66 \mathrm{qrs}$ & $2.56 \mathrm{p}$ \\
\hline & PRM,2008 & 2.14 & 1.21 & 0.89 & 1.89 & 1.34 & 3.21 \\
\hline & MON,2008 & 1.89 & 1.2 & 1.21 & 0.98 & 0.54 & 1.79 \\
\hline & POM,2008-2009 & 1.5 & 1.46 & 2.17 & 2.2 & 1.79 & 1.89 \\
\hline & & \multicolumn{3}{|c|}{$\begin{array}{l}\text { Available Potassium } \\
\qquad(\mathrm{mg} / \mathrm{gm})\end{array}$} & \multicolumn{3}{|c|}{$\begin{array}{l}\text { Available Nitrogen } \\
\qquad(\mathrm{mg} / \mathrm{gm})\end{array}$} \\
\hline & Total & $0.66 \mathrm{pq}$ & $0.66 \mathrm{p}$ & $0.90 \mathrm{p}$ & $7.66 \mathrm{p}$ & $7.71 \mathrm{rs}$ & $9.01 \mathrm{p}$ \\
\hline & PRM,2008 & 0.28 & 0.29 & 0.48 & 5.33 & 7.12 & 7.24 \\
\hline & MON,2008 & 0.53 & 0.32 & 0.27 & 8.62 & 5.78 & 4.87 \\
\hline & POM,2008-2009 & 1.08 & 1.34 & 1.24 & 6.44 & 8.69 & 12.74 \\
\hline \multirow{8}{*}{ S. taeniolatum } & Total & $1.84 \mathrm{pq}$ & $1.29 \mathrm{pq}$ & $1.42 \mathrm{p}$ & $1.69 \mathrm{qr}$ & $1.22 \mathrm{qrs}$ & $2.30 \mathrm{pq}$ \\
\hline & PRM,2008 & 1.4 & 1.24 & 0.78 & 3.22 & 2.28 & 1.24 \\
\hline & MON,2008 & 1.12 & 1.04 & 1.34 & 2.24 & 2.08 & 0.84 \\
\hline & POM,2008-2009 & 1.66 & 2.2 & 2.2 & 3.45 & 4.28 & 2.46 \\
\hline & Total & $0.63 \mathrm{pq}$ & $0.65 \mathrm{p}$ & $0.66 \mathrm{p}$ & $6.80 \mathrm{pq}$ & $7.20 \mathrm{rs}$ & $8.28 \mathrm{pq}$ \\
\hline & PRM,2008 & 0.72 & 0.47 & 0.26 & 10.24 & 13.42 & 7.48 \\
\hline & MON,2008 & 0.68 & 0.4 & 0.24 & 8.24 & 10.35 & 5.58 \\
\hline & POM,2008-2009 & 0.68 & 0.85 & 1.25 & 4.44 & 11.2 & 11.48 \\
\hline \multirow{8}{*}{ M. maculatus } & Total & $1.39 \mathrm{pqr}$ & $1.49 \mathrm{p}$ & $1.44 p$ & $2.97 \mathrm{p}$ & $2.88 \mathrm{p}$ & $1.51 \mathrm{qrs}$ \\
\hline & PRM,2008 & 0.69 & 0.42 & 0.44 & 0.64 & 1.24 & 1.3 \\
\hline & MON,2008 & 0.22 & 0.22 & 0.34 & 0.54 & 0.76 & 0.66 \\
\hline & POM,2008-2009 & 2.45 & 2.65 & 2.85 & 1.2 & 1.28 & 1.45 \\
\hline & Total & $0.69 \mathrm{pq}$ & $0.57 \mathrm{p}$ & $0.58 \mathrm{p}$ & $7.64 p$ & $11.66 \mathrm{p}$ & $8.18 \mathrm{pq}$ \\
\hline & PRM,2008 & 0.58 & 0.74 & 0.44 & 3.23 & 6.26 & 4.24 \\
\hline & MON,2008 & 0.35 & 0.55 & 0.55 & 3.54 & 5.55 & 4.48 \\
\hline & POM,2008-2009 & 1.2 & 1.48 & 1.85 & 4.2 & 6.55 & 4.48 \\
\hline \multirow{8}{*}{ M. intermedia } & Total & $1.12 \mathrm{qrs}$ & $1.10 \mathrm{pqr}$ & $1.21 \mathrm{p}$ & $0.79 \mathrm{st}$ & $1.09 \mathrm{rs}$ & $1.14 \mathrm{rs}$ \\
\hline & PRM,2008 & 0.48 & 0.18 & 0.25 & 0.68 & 1.16 & 1.05 \\
\hline & MON,2008 & 0.25 & 0.06 & 0.16 & 0.46 & 0.88 & 0.65 \\
\hline & POM,2008-2009 & 0.25 & 0.06 & 0.16 & 0.46 & 0.88 & 0.65 \\
\hline & Total & $0.71 \mathrm{pq}$ & $0.92 p$ & $0.95 \mathrm{p}$ & $3.66 \mathrm{rs}$ & $6.12 \mathrm{st}$ & 4.40rs \\
\hline & PRM,2008 & 1.04 & 0.78 & 0.47 & 2.44 & 8.24 & 3.22 \\
\hline & MON,2008 & 0.84 & 0.58 & 0.35 & 1.68 & 6.42 & 3.06 \\
\hline & POM,2008-2009 & 0.84 & 0.58 & 0.35 & 2.24 & 7.45 & 4.45 \\
\hline
\end{tabular}


Table 7. The mean effect of different nutritional quantity of gut contents (GC), excavated soil (ES) and soils surrounding burrows (SSB) between species and seasons with Duncan's test results

\begin{tabular}{|c|c|c|c|c|c|c|c|}
\hline \multirow[t]{2}{*}{ Species } & \multirow[t]{2}{*}{ Seasons } & \multicolumn{3}{|c|}{$\begin{array}{c}\text { Organic Carbon } \\
(\%)\end{array}$} & \multicolumn{3}{|c|}{$\begin{array}{l}\text { Available Phosphorus } \\
\qquad(\mathrm{mg} / \mathrm{gm})\end{array}$} \\
\hline & & GC & ES & SSB & GC & ES & SSB \\
\hline \multirow{10}{*}{ O. macrocera } & Total & $0.33 \mathrm{st}$ & $0.10 \mathrm{t}$ & $0.19 \mathrm{r}$ & $0.53 \mathrm{st}$ & $0.97 \mathrm{~s}$ & $0.78 \mathrm{~s}$ \\
\hline & PRM,2008 & 0.33 & 0.04 & 0.23 & 0.32 & 1.01 & 0.89 \\
\hline & MON,2008 & 0 & 0.04 & 0.08 & 0.2 & 0.85 & 0.82 \\
\hline & POM,2008-2009 & 0 & 0.07 & 0.08 & 0.28 & 0.94 & 0.92 \\
\hline & & \multicolumn{3}{|c|}{$\begin{array}{l}\text { Available Potassium } \\
\qquad(\mathrm{mg} / \mathrm{gm})\end{array}$} & \multicolumn{3}{|c|}{$\begin{array}{l}\text { Available Nitrogen } \\
\qquad(\mathrm{mg} / \mathrm{gm})\end{array}$} \\
\hline & & GC & ES & SSB & GC & ES & SSB \\
\hline & PRM 20 & $0.91 \mathrm{p}$ & $0.65 p$ & $0.39 p$ & $2.12 \mathrm{rs}$ & $7.37 \mathrm{rs}$ & $3.58 \mathrm{rs}$ \\
\hline & MON 2008 & 0.46 & 0.54 & 0.58 & 1.04 & 2.24 & 2.12 \\
\hline & MOUT, 2000 & 0.33 & 0.44 & 0.56 & 1.22 & 1.84 & 2.08 \\
\hline & & 0.44 & 0.64 & 0.76 & 2.2 & 4.6 & 3.25 \\
\hline \multirow{8}{*}{ D. blanfordi } & Total & $0.11 \mathrm{t}$ & $0.05 \mathrm{t}$ & $0.13 r$ & $0.27 \mathrm{t}$ & $0.93 \mathrm{~s}$ & $0.88 \mathrm{~s}$ \\
\hline & PRM,2008 & 0.06 & 0.22 & 0.12 & 0.45 & 2.1 & 1.48 \\
\hline & MON,2008 & 0.02 & 0.04 & 0.22 & 0.64 & 1.84 & 1.4 \\
\hline & POM,2008-2009 & 0.03 & 0.08 & 0.72 & 0.54 & 2.25 & 3.24 \\
\hline & Total & $0.41 \mathrm{q}$ & $0.54 \mathrm{p}$ & $0.63 p$ & $1.49 \mathrm{~s}$ & $2.89 \mathrm{u}$ & $2.48 \mathrm{~s}$ \\
\hline & PRM,2008 & 0.64 & 0.47 & 0.32 & 1.08 & 5.47 & 4.28 \\
\hline & MON,2008 & 0.4 & 0.45 & 0.56 & 1.14 & 3.42 & 4.8 \\
\hline & POM,2008-2009 & 0.48 & 0.65 & 0.72 & 2.2 & 3.48 & 5.24 \\
\hline \multirow{8}{*}{ D. brevitarsis } & Total & $0.04 \mathrm{t}$ & $0.11 \mathrm{~s}$ & $0.35 \mathrm{qr}$ & $0.54 \mathrm{st}$ & $2.06 \mathrm{pqr}$ & $2.04 \mathrm{pqr}$ \\
\hline & PRM,2008 & 0.74 & 0.84 & 0.45 & 0.94 & 1.84 & 1.05 \\
\hline & MON,2008 & 0.66 & 0.74 & 0.64 & 1.04 & 2.14 & 1.24 \\
\hline & POM,2008-2009 & 0.68 & 0.82 & 0.7 & 1.54 & 2.6 & 2.4 \\
\hline & Total & $0.51 \mathrm{pq}$ & $0.52 \mathrm{p}$ & $0.53 p$ & $1.47 \mathrm{~s}$ & $4.12 \mathrm{tu}$ & 4.77qrs \\
\hline & PRM,2008 & 0.64 & 0.58 & 0.32 & 5.4 & 10.47 & 5.24 \\
\hline & MON,2008 & 0.42 & 0.52 & 0.22 & 4.5 & 9.44 & 6.4 \\
\hline & POM,2008-2009 & 0.72 & 0.75 & 0.85 & 3.45 & 7.2 & 5.25 \\
\hline \multirow{8}{*}{ U. acuat acuta } & Total & 0.69 rst & $0.80 \mathrm{pqr}$ & $0.60 \mathrm{pqr}$ & $1.17 \mathrm{rs}$ & $2.19 \mathrm{pq}$ & $1.56 \mathrm{pqrs}$ \\
\hline & PRM,2008 & 0.89 & 0.66 & 0.54 & 1.64 & 2.83 & 1.33 \\
\hline & MON,2008 & 0.75 & 0.54 & 0.48 & 1.42 & 1.84 & 1.46 \\
\hline & POM,2008-2009 & 0.7 & 0.62 & 0.55 & 1.55 & 1.95 & 1.6 \\
\hline & Total & $0.59 \mathrm{pq}$ & $0.62 p$ & $0.46 p$ & $4.45 \mathrm{q}$ & $9.04 \mathrm{qr}$ & 5.63pqrs \\
\hline & PRM,2008 & 0.6 & 0.8 & 0.49 & 5.82 & 9.78 & 7.45 \\
\hline & MON,2008 & 0.55 & 1.08 & 1.08 & 3.45 & 6.4 & 5.45 \\
\hline & POM,2008-2009 & 0.75 & 1.24 & 1.05 & 4.5 & 6.8 & 6.35 \\
\hline
\end{tabular}


Table 8. The mean effect of different nutritional quantity of gut contents (GC), excavated soil (ES) and soils surrounding burrows (SSB) between species and seasons with Duncan's test results

\begin{tabular}{|c|c|c|c|c|c|c|c|}
\hline \multirow[t]{2}{*}{ Species } & \multirow[t]{2}{*}{ Seasons } & \multicolumn{3}{|c|}{$\begin{array}{c}\text { Organic Carbon } \\
(\%)\end{array}$} & \multicolumn{3}{|c|}{$\begin{array}{l}\text { Available Phosphorus } \\
\qquad(\mathrm{mg} / \mathrm{gm})\end{array}$} \\
\hline & & $\mathrm{GC}$ & ES & SSB & $\mathrm{GC}$ & ES & SSB \\
\hline \multirow{10}{*}{ U. lactea annulipes } & Total & $0.78 \mathrm{rst}$ & $0.61 \mathrm{qrs}$ & $0.52 \mathrm{pqr}$ & $1.54 \mathrm{qr}$ & $2.21 \mathrm{pq}$ & $1.46 \mathrm{qrs}$ \\
\hline & PRM,2008 & 0.82 & 0.24 & 0.74 & 1.67 & 2.05 & 1.11 \\
\hline & MON,2008 & 0.86 & 0.54 & 1.01 & 1.67 & 2.05 & 1.11 \\
\hline & POM,2008-2009 & 0.48 & 0.14 & 0.24 & 1.08 & 1.2 & 1.55 \\
\hline & & \multicolumn{3}{|c|}{$\begin{array}{c}\text { Available Potassium } \\
(\mathrm{mg} / \mathrm{gm})\end{array}$} & \multicolumn{3}{|c|}{$\begin{array}{c}\text { Available Nitrogen } \\
(\mathrm{mg} / \mathrm{gm})\end{array}$} \\
\hline & Total & $\mathrm{GC}$ & ES & SSB & $\mathrm{GC}$ & ES & SSB \\
\hline & PRM 2008 & $0.63 \mathrm{pq}$ & $1.04 \mathrm{p}$ & $0.87 \mathrm{p}$ & $4.59 \mathrm{qr}$ & $7.66 \mathrm{rs}$ & $6.42 \mathrm{pqr}$ \\
\hline & MON.2008 & 0.28 & 0.49 & 0.34 & 5.23 & 11.72 & 3.21 \\
\hline & POM 2008-2009 & 0.16 & 0.79 & 0.99 & 5.23 & 11.72 & 3.21 \\
\hline & & 0.58 & 0.65 & 0.64 & 2.68 & 8.82 & 10.25 \\
\hline \multirow{8}{*}{ U. triangularis bengali } & Total & 0.72 rst & $0.31 \mathrm{rs}$ & $0.66 \mathrm{pqr}$ & $1.47 \mathrm{qr}$ & $1.77 \mathrm{qrs}$ & $1.26 \mathrm{qrs}$ \\
\hline & PRM,2008 & 2.8 & 1.66 & 1.07 & 2.24 & 1.86 & 3.25 \\
\hline & MON,2008 & 2.24 & 1.35 & 0.89 & 1.04 & 0.89 & 2.24 \\
\hline & POM,2008-2009 & 1.58 & 1.88 & 2.1 & 2.54 & 2.24 & 2.2 \\
\hline & Total & $0.34 q$ & $0.64 \mathrm{p}$ & $0.66 p$ & $4.38 \mathrm{qr}$ & $10.75 \mathrm{pq}$ & $5.56 \mathrm{pqrs}$ \\
\hline & PRM,2008 & 0.33 & 0.25 & 0.68 & 7.26 & 8.22 & 9.22 \\
\hline & MON,2008 & 0.44 & 0.24 & 0.48 & 8.24 & 6.48 & 5.58 \\
\hline & POM,2008-2009 & 1.2 & 1.48 & 1.55 & 7.48 & 8.42 & 12.24 \\
\hline \multirow{6}{*}{ Seasons } & PRM,2008 & $1.04 \mathrm{a}$ & $0.67 \mathrm{a}$ & $0.55 \mathrm{~b}$ & $1.37 \mathrm{ab}$ & $1.77 \mathrm{ab}$ & $1.59 \mathrm{ab}$ \\
\hline & MON,2008 & $0.80 \mathrm{a}$ & $0.58 \mathrm{a}$ & $0.64 \mathrm{~b}$ & $1.02 \mathrm{~b}$ & $1.39 \mathrm{~b}$ & $1.22 \mathrm{~b}$ \\
\hline & POM,2008-2009 & $0.93 \mathrm{a}$ & $1.00 \mathrm{a}$ & $1.18 \mathrm{a}$ & $1.48 \mathrm{a}$ & $1.94 \mathrm{a}$ & $1.84 \mathrm{a}$ \\
\hline & PRM,2008 & $0.56 \mathrm{~b}$ & $0.54 \mathrm{~b}$ & $0.44 \mathrm{~b}$ & $4.71 \mathrm{a}$ & $8.29 \mathrm{a}$ & $5.37 \mathrm{~b}$ \\
\hline & MON,2008 & $0.47 \mathrm{~b}$ & $0.54 \mathrm{~b}$ & $0.53 b$ & $4.59 \mathrm{a}$ & $6.74 \mathrm{~b}$ & $4.50 \mathrm{~b}$ \\
\hline & POM,2008-2009 & $0.80 \mathrm{a}$ & $0.97 \mathrm{a}$ & $1.03 \mathrm{a}$ & $3.98 \mathrm{a}$ & $7.32 \mathrm{ab}$ & $7.57 \mathrm{a}$ \\
\hline
\end{tabular}

\section{Discussion}

Brachyuran crabs are common intertidal inhabitants of salt marshes and mangrove swamps along tropical, neotropical, and temperate coast lines. These animals have adapted to a wide range of temperature, salinity, and relative humidity (Cannicci et al., 2000). Their burrowing and feeding activities increase the rates of sediment (and presumably nutrient) turnover within these systems (Katz, 1980). Their deposit feeding habit also significantly affect the taxonomic composition and production of epibenthic microbiota (Foreman, 1985; Riisgard and Kamermans, 2001), meiofauna and increase the level of oxygenation of the surface sediments (Hoffman et al., 1984). 
Coastal belt is unified as a system by low gradients, low wave energy, fine grained sediments and pervasive salt water influences (Semeniuk, 2008). It supports a luxuriant growth of mangrove forests and a faunistic community quite rich in variety and abundance, of which the brachyuran constitute one of the most important faunal groups. The mudflat mangrove swamps interaction is geomorphologically very significant as the incoming rivers bring down fresh silts, raise the level of shore-fringe mud flats and sediments are redistributed into the swamps by tidal drift at the high tides (Paul, 2002). The mudflats enriched with mangrove contributed detritus, support a variety of benthic fauna - throbbing with the tidal inundation and exposure (Chakraborty, 2011; Chakraborty et al., 2012, Chakraborty, 2013). Herbivorous crabs (sesarmid crabs) get benefit from the amount of primary production but assimilates only a fraction of the available energy, while the reminders fuels the microbial loop in the detritus compartment enhancing the food supply of the deposit-feeding crabs i.e. fiddler crabs. The three benefits from the activities of crabs and bacteria are as: (1) nutrients are retained in the system by herbivorous crabs rather than transporting to sub tidal region by tidal action; (2) nutrient re-mineralization is enhanced in the system through shredding of the leaf material and the high grazing pressure exerted on microbes; and (3) the soil is aerated by the burrowing and feeding activities of the crabs, thus preventing the formation of phytotoxins such as $\mathrm{H}_{2} \mathrm{~S}$ in the sediments (Koch \& Wolff, 2002).

The nutrients are the significant ingredients in coastal ecosystem because of their role in the production of phytoplankton, the bottom of the food webs. Nutrient availability affects primary productivity in salt-marsh ecosystems (Mukhopadhyay et al., 2006). Analysis of litter collected from soil around the burrows may help to reveal preferences regarding leaf litter type and decomposition stage. Litter materials i.e. soil of surrounding burrows were therefore dug out of the burrows by different selected crabs and investigated for its proportional composition and decomposition stage. The goal of this study was to estimate the daily food consumption of different selected crab based on data from GC, ES and SSB. Crabs and other benthic detritivores initially process nearly $50 \%$ of the total litterfall produced in many forests (Alongi, 2009). The rest of the materials are swept away by the tides but any litter remaining in the forest is then further decomposed by various microbial assemblages. Leaf-eating crabs play an important role in leaf degradation (Koch and Wolff, 2002). Through the process of digestion, mangrove leaves are returned to the environment as finely shredded and partially digested faecal materials (Camilleri, 1989; Robertson \& Daniel, 1989), which are more readily consumed by detritivores and provides more surface area for colonization by microorganisms than the undigested leaves. Detritus materials formed from mangrove leaf litter is considered to be the basis of food webs within mangrove ecosystems (Odum \& Heald, 1972). The rapid conversion of leaf litter into finer detritus greatly accelerates the cycling of nutrients within the mangrove system (Robertson \& Daniel, 1989). The litter consumption by the brachyuran crabs accelerates nutrient cycling and represents an important input in mangrove productivity, through nutrient retention (Koch \& Wolff, 2002; Nordhaus et al., 2007). Mangrove mud is often honeycombed with a network of interconnecting passages, occupied by a population of crabs. Mangroves provide basic inputs of carbon to estuaries primarily in the form of dead leaves and branches. Mangroves are not usually eaten directly by herbivores, except by some insects and crabs (for example: sesarmid crabs), which eat the green leaves, fallen mangrove 
leaves and seedlings. Most mangrove debris is subject to breakdown by bacteria and fungi before it is made available to the food chain of aquatic animals.

Brachyuran crabs act as a macro-decomposer; decomposition involves three processesfragmentation, leaching and decay (Robertson \& Daniel, 1989; Lee, 2008). Nutrient cycle is a pathway by which a chemical element or molecule moves through both biotic (biosphere) and abiotic (lithosphere, atmosphere, and hydrosphere) compartments of Earth. Crabs influence nutrient cycling within mangrove forests by their burrowing activities (Smith III et al., 1991). Plants need nutrients from the soil to grow, just like people need food. Sesarmid crabs the primary consumers of litter in mangroves. The influence of Sesarmid crabs on mangrove forest nutrient dynamics is twofold (Robertson, 1988). The removal of $22-83 \%$ of litter and a proportion of propagules contributes significantly to nutrient retention and cycling within the forest (Robertson and Daniel, 1989) and the burrowing activities of the crabs stimulates sediment turnover affecting nutrient transformation (Smith III et al., 1991).

Nineteen species of mangrove and their associated plants have been found to occur in different study sites viz. Acanthus ilicifolius, Aegiceros corniculatum, Avicennia officinalis, A. marina, A. alba, Bruguiera gymnorhiza, Casuarina equisetifolia, Ceriops decandra, Excoecaria agallocha, Ipomoea pes-caprae, Myriostachya wightiana, Porteresia coarctata, Rhizophora mucronata, Rhizophora apiculata, Sesuvium portulacastrum, Salicornia brachiata, Sonneratia apetala, Spinifex littoreus, Suaeda maritime (Chatterjee et al., 2004). Leaves of Rhizophora mucronata have high concentrations of soluble tannins, low percentage of nitrogen content (Mfilinge et al., 2002; Skov \& Hartnoll, 2002) and high C: N ratios which would decrease palatability of the leaves, while leaves of A. marina and A. germinans, have low tannin concentrations, high \% of nitrogen content and low C: $\mathrm{N}$ ratios (Lacerda et al., 1995), making these leaves more favorable and energy efficient animal food (Feller et al., 2007). Acanthus ilicifolius, Avicennia officinalis, A. marina, A. alba, Bruguiera gymnorhiza and Suaeda maritime represented the dominant species of different study sites. Burrowing grapsid and ocypodid crabs usually dominate the benthic infauna of mangroves and they have been considered as 'ecosystem engineers' (Kristensen, 2008).

Living mangroves contain about 50\% lignocellose, a highly refractory structural complex consisting of the aromatic hetero polymer lignin, in close physical and covalent association with the polysaccharides, cellulose and hemicellulose (Benner \& Hodson, 1985). Yet, leaf feeders, including insect and crab species, consume large quantities of mangrove leaves, typically ranging from 1 to 30 percent of leaf area (Feller et al., 2007). In contrast, certain leaf feeders, such as the mangrove tree crab Arums pisonii H. M. Edwards (Grapsidae), eat fresh leaves still on the tree. Grapsid crabs have been accorded the status of 'keystone species' based on their strong influence on mangrove structure and function (Smith III et al., 1991). Mangrove detritus is still a key food resource and plays an equally important role in nutrient recycling and retention to help sustain high rates of net canopy production (Alongi, 2009). Organic carbon, available phosphorous, available potassium and available nitrogen represent important nutrients of the soil influencing macrobenthic faunal abundance in an estuarine ecosystem. Knowledge about the food spectrum and preferences of an organism is fundamental for the understanding of its feeding ecology and functional role within the food web. 
S. (Chiromantes) bidens, S. taeniolatum and M. maculatus collect fresh leaves as well as litter when the forest is not inundated and may then feed on it inside the burrows independently. The foraging activities of these three species outside the burrows depended on forest inundation, non on the feeding on litter inside burrows. Avicennia leaves have been found to be the preferred food item of Sesarma erythrodactyla (Camilleri, 1989). Benthic fauna accounted for only a small part of the diet of M. maculatus and S. (Chiromantes) bidens which were most likely ingested during the consumption of sediment. The proportion of animal part remains in the stomach of $S$. (Chiromantes) bidens, $S$. taeniolatum and $M$. maculatus was too low to be considered nutritionally insignificant. Observations of the feeding behaviour also confirm that the $S$. (Chiromantes) bidens, $S$. taeniolatum and $M$. maculatus do not prey on the epibenthos and infauna. Depending upon the mode of feeding, it can be concluded that $S$. (Chiromantes) bidens, S. taeniolatum and $M$. maculatus were the true mangrove feeders and scavengers. Substrates are important in determining the species composition of the various habitats. Numerically dominant species were usually morphologically specialized to some aspects of their substrate (Abele, 1973). Food preferences of $U$. acuta acuta, U. lactea annulipes, $U$. triangularis bengali and $O$. macrocera, D. blanfordi, D. brevitarsis, $M$. intermedia probably depend on other food characteristics and on the ability to digest and assimilate the different food components. Brachyuran especially fiddler crabs feed by scooping sediments into their buccal cavities where water from the branchial chamber is used to suspend organic materials (Miller, 1961). Many deposit-feeding fiddler crabs have a main feeding peak during low tide at daylight. A secondary, smaller feeding peak at night was observed for $U$. maracoani and $U$. cumulanta (Koch \& Wolf, 2002), probably compensating for shortened feeding periods during the day (Macintosh, 1988).

The present study was initiated to examine one of the steps in the detritus food chain linking primary production of intertidal belts to production of coastal fisheries. This research also provides evidence that the selected species of different brachyuran especially sesarmid crab is a significant agent in the breakdown of mangrove leaf litter to detritus sized particles. Several previous researchers, using gut content analysis, have contended that fiddler crabs rely upon mixture of both benthic algae and detritus (Crane, 1975). The present results (Table 2) for different selected species of brachyuran crabs also indicated the same characteristics.

Different traits among the different nutrients contents viz. organic carbon, available phosphorus, available potassium and available nitrogen analyzed from the gut contents, excavated soil and soils surrounding burrows of different studied species were found varying from species to species and seasonally. Among the different studied species, it is noted that $S$. (Chiromantes) bidens, S. taeniolatum and M. maculatus played a key role in the nutrients recycling followed by $U$. lactea annulipes, $U$. triangularis bengali, $U$. acuta acuta, $O$. macrocera, $M$. intermedia, D. blanfordi and D. brevitarsis in turns of nutritional status of gut contents (GC), excavated soil (ES) and soils surrounding burrows (SSB) vis-à-vis mangrove litter degradation during different seasons. Sesarmid crabs are important for the carbon and nutrient cycling in mangrove environments by their leaf eating habit and subsequent fecal pellet deposition to the sediment. From the Chi square test, it was concluded that the effect of season on the diet of different studied species of brachyuran crabs to eat mangrove leaf (Ml), 
degraded leaf particles (Dlp), different algae (Da), animal parts (Ap) and detritus (D) as food was not significant at 5\% and unidentified materials (Um) as food was significant at $1 \%$ level of significance. ANOVA analyses between species and season on different nutrient contents in the form of organic carbon, available phosphorus, available potassium and available nitrogen within the gut contents (GC), excavated soil (ES) and soil surrounding burrows (SSB) showed that significant main effects along with species and season. Regarding the main effects of species and seasons on different nutritional contents when compared by Duncan's test $(5 \%)$ the mean of different nutrient contents within GC, ES and SSB is significantly deviated among the different species and seasons.

\section{Acknowledgements}

First author is thankful to Ministry of Environment and Forest, Government of India for financial support for providing research fellowship [Sanctioned No. 3/6/2001-CSC (M) dated $5^{\text {th }}$ Nov.2001]. Authors are thankful to the authority of Vidyasagar University for providing library, laboratory and internet facilities.

\section{References}

Abele, L.G. (1973). Taxonomy, distribution and ecology of the genus Sesarma (Crustacea, Decapoda, Grapsidae) in Eastern- North America, with special reference to Florida. The American Midland Naturalist. 90, 375-386. http://dx.doi.org/10.2307/2424461

Alongi, D.M. (1990). Effects of mangrove detrital outwelling on nutrient regeneration and oxygen fluxes in coastal sediments of the central Great Barrier Reef lagoon. Estuarine, Coastal and Shelf Science, pp. 581-598. http://dx.doi.org/10.1016/0272-7714(90)90014-I

Alongi, D.M. (2009). The Energetics of Mangrove Forests. Springer, pp. 1-216.

Benner, R., \& Hodson, R. E. (1985). Microbial degradation of the leachable and lignocellulosic components of leaves and wood from Rhizophora mangle in a tropical mangrove swamp. Marine Ecology Progress Series, 23, 221-230. http://dx.doi.org/10.3354/meps023221

Bertness, M. D. (1985). Fiddler crab regulation of Spartina alterniflora production on a New Eagland salt marsh. Ecology, 66, 1042-1055. http://dx.doi.org/10.2307/1940564

Botto, F., \& Iribarne, O. (2000). Contrasting effects of two burrowing crabs (Chasmagnathus granulata and Uca uruguayensis) on sediment composition and transport in estuarine environments. Estuarine, Coastal and Shelf Science, 51, 141- 151. http://dx.doi.org/10.1006/ecss.2000.0642

Botto, F., Iribarne, O., Gutierrez, J., Bava, J., Gagliardini, A., \& Valiela, I. (2006). Ecological importance of passive deposition of organic matter into burrows of the SW Atlantic crab Chasmagnathus granulatus. Marine Ecology Progress Series, 312, 201-210. http://dx.doi.org/10.3354/meps312201

Botto, F., Valiela, I., Iribarne, O., Martinetto, P., \& Alberti, J. (2005). Impact of burrowing crabs on $\mathrm{N}$ and $\mathrm{N}$ sources, control, and transformations in sediments and food webs of SW Atlantic estuaries. Marine Ecology Progress Series, 293, 155-164. 
http://dx.doi.org/10.3354/meps293155

Buck, T. L., Breed, G. A., Pennings, S. C., Chase, M. E., Zimmer, M., \& Carefoot, T. H. (2003). "Diet choice in an omnivorous salt-marsh crab: different food types, body size, and habitat complexity". Journal of Experimental Marine Biology and Ecology, 292(1), 103-116. http://dx.doi.org/10.1016/S0022-0981(03)00146-1

Camilleri, J. C. (1989). Leaf choice by crustaceans in a mangrove forest in Queensland. Marine Biology, 102, 453-459. http://dx.doi.org/10.1007/BF00438346

Cannicci, S., Skov, M.W., \& Vannini, M. 2000. The influence of abiotic and biotic factors on the distribution of mangrove crabs at Mida Creek (Kenya): a multivariate approach. Abstract Volume of the Meeting on Mangrove Macrobenthos, 7-11 September, Mombasa, Kenya, pp. 20-21.

Chakraborty, S. K. (2010). Coastal Environment of Midnapore, West Bengal: Potential Threats and Management. Journal of Coastal Environment, Vol.1, No. 1.

Chakraborty, S. K. (2011). Mangrove Ecosystem of Sundarbans, India; Biodiversity, Ecology, Threats and Conservation. In. Mangroves: Ecology, Biology and Taxonomy. Ed. James N. Metras (Publ. NOVA publishers) pp.83-112.

Chakraborty, S. K. (2013). Interactions of environmental variables determining the biodiversity of coastal- mangrove ecosystem of West Bengal, India. The Ecoscan, Special issue, Vol. III. 251-265.

Chakraborty, S. K., Chatterjee, S., Dey, M.K., Bhakat, R.K., \& Paul, A.K. (2012). Ecological Changes of an Eco-rehabilitated Delta of Hooghly Estuary. Journal of Coastal Environment, vol.3 No. 1.

Chatterjee, S., Chakraborty, S. K., Chakravarty, G., Chandra, A., \& Khalua, R. K. (2004). Distributional pattern of mangroves and associated floral and faunal components of East Midnapore district coastal tract, West Bengal, India. Paper presented in the national seminar on State of the art on Conservation of biodiversity in India with particular reference to Himalaya. Held on $22^{\text {nd }}$ to $24^{\text {th }}$ March, 2004. Organised by CORD and PG Department of Environmental Science, University of Kashmir, India.

Clough, B. F. (1992). Primary Productivity and growth of mangrove forests. In:Robertson, AI. and Alongi, DM.(Eds.) Tropical Mangrove Ecosystems, American Geophysical Union, Washington, DC. pp. 225-250. http://dx.doi.org/10.1029/CE041p0225

Conley, D. J. (2000). Biogeochemical nutrient cycles and nutrient management strategies. Hydrobiologia , 410, 87-96. http://dx.doi.org/10.1023/A:1003784504005

Crane, J. (1975). Fiddler Crabs of the World (Ocypodidae: genus Uca). Princeton, NJ: Princeton University Press.

Daleo, P., \& Iribarne, O. (2009). The burrowing crab Neohelice granulate affects the root strategies of the cordgrass Spartina densiflora in SW Atlantic salt marshes. Journal of 
Experimental Marine Biology and Ecology, 373, 66-71. http://dx.doi.org/10.1016/j.jembe.2009.03.005

Dworschak, P. C., \& Ott, J. A. (1993). Decapod burrows in mangrove-channel and back-reef environments at the Atlantic Barrier Reef, Brazil. Ichnos, 2, 277-290. http://dx.doi.org/10.1080/10420949309380103

Dye, A. H., \& Lasiak, T. A. (1986). Microbenthos, meiobenthos and fiddler crabs: trophic interactions in tropical mangrove sediment. Marine Ecology Progress Series, 32 (2\&3). 259-264. http://dx.doi.org/10.3354/meps032259

Fanjul, E., Grela, M. A., \& Iribarne, O. (2007). Effects of the dominant SW Atlantic intertidal burrowing crab Chasmagnathus granulates on sediment chemistry and nutrient distribution. Marine Ecology Progress Series, 341, 177-90. http://dx.doi.org/10.3354/meps341177

Fanjul, E., Grela, M. A., Canepuccia, A., \& Iribarne, O. (2008). The Southwest Atlantic intertidal burrowing crab Neohelice granulate modifies nutrient loads of phreatic waters entering coastal area. Estuarine, Coastal and Shelf Science, 79, 300-306. http://dx.doi.org/10.1016/j.ecss.2008.04.005

Feller, I. C., Lovelock, C. E., \& McKee, K. L. (2007). Nutrient addition differentially affects ecological processes of Avicennia germinans in nitrogen versus phosphorus limited mangrove ecosystems. Ecosystems, 10, 347-359. http://dx.doi.org/10.1007/s10021-007-9025-z

Foreman, K. (1985). Do predators, resources or physical factors control the seasonal cycle of meiofauna of marshes? Estuaries, 8, 48.

France, R. L. (1998). Estimation of the assimilation of mangrove detritus by fiddler crabs in Laguna Joyuda, Puerto Rico, using dual stable isotopes. Journal of Tropical Ecology, 14, 413-425. http://dx.doi.org/10.1017/S0266467498000315

Genoni, G. P. (1991). Increase burrowing by fiddler crabs Uca rapax (Smith)[Decapoda: Ocypodidae] in response to low food supply. Journal of Experimental Marine Biology and Ecology, 147(2), 267-285. http://dx.doi.org/10.1016/0022-0981(91)90186-Z

Hoffman, J. A., Katz, J., \& Bertness, M. D. (1984). Fiddler crab deposit-feeding and meiofaunal abundance in salt marsh habitats. Journal of Experimental Marine Biology and Ecolog, 82, 161-174. http://dx.doi.org/10.1016/0022-0981(84)90101-1

Holmboe, N., Kristensen, E., \& Andersen, F. Q. (2001). Anoxic decomposition in sediments from a tropical mangrove forest and the temperate Wadden sea: Implications of $\mathrm{N}$ and $\mathrm{P}$ addition Experiments. Estuarine, Coastal and Shelf Science, 53, 125-140. http://dx.doi.org/10.1006/ecss.2000.0794

Iribarne, O., Bortolus, A., \& Botto, F. (1997). Between-habitat differences in burrowcharacteristics and trophic modes in the southwestern Atlantic burrowing crab Chasmagnathus granulata. Marine Ecological Progress Series, 155, 137-45. http://dx.doi.org/10.3354/meps155137 
Katz, L. C. (1980). The effects of the burrowing of the fiddler crab Ucapugnax (Smith). Estuarine and Coastal Marine Science, 4, 233-237. http://dx.doi.org/10.1016/S0302-3524(80)80043-0

Koch, V., \& Wolff, M. (2002). Energy budget and ecological role of mangroveepibenthos in the Caeté estuary, North Brazil. Marine Ecological Progress Series, 228, 119-130. http://dx.doi.org/10.3354/meps228119

Kristensen, E. (2008). Mangrove crabs as ecosystem engineers; with emphasis on sediment processes. Journal of Sea Research, 59, 30-43. http://dx.doi.org/10.1016/j.seares.2007.05.004

Lacerda, L. D., Ittekkot, V., \& Patchineelam, S. R. (1995). Biogeochemistry of Mangrove soil organic matter: a comparison between Rhizophora and Avicennia soils in south-eastern Brazil. Estuarine, Coastal and Shelf Science, 40, 713-720. http://dx.doi.org/10.1006/ecss.1995.0048

Lee, S. Y. (1998). Ecological role of grapsid crabs in mangrove ecosystems: a review, Marine Freshwater Research, 49, 335-343. http://dx.doi.org/10.1071/MF97179

Lee, S. Y. (2008). Mangrove macrobenthos: assemblages, services, and linkages. Journal of Sea Research, 59, 16-29. http://dx.doi.org/10.1016/j.seares.2007.05.002

Macintosh, D. J. (1988). The ecology and physiology of decapods of mangrove swamps. Symposia of the Zoological Society, London, 59, 315-341.

Malley, D. F. (1978). Degradation of mangrove leaf litter by the tropical sesarmid crab Chiromanthes onychophorum. Marine Biology, 49, 377-386. http://dx.doi.org/10.1007/BF00455032

Mfilinge, P.L., Atta, N., \& Tsuchiya, M. (2002). Nutrient dynamics and leaf litter decomposition in a subtropical mangrove forest at Oura Bay, Okinawa, Japan. Trees, 16, 172-180. http://dx.doi.org/10.1007/s00468-001-0156-0

Miller, D. C. (1961). The feeding mechanism of fiddler crabs with ecological consideration of feeding adaptations. Zoologica, N.Y.46. 86-100.

Mukhopadhyay, S. K., Biswas, H., De, T. K., \& Jana, T. K. (2006). Fluxes of nutrients fromthe tropical River Hooghly at the land-ocean boundary of Sunderbans, NE coast of Bay of Bengal, India. Journal of Marine System, 62, 9-21. http://dx.doi.org/10.1016/j.jmarsys.2006.03.004

Neira, C., Grosholz, E. D., Levin, L. A., \& Blake, R. (2006). Mechanisms generating modification of benthos following tidal flat invasion by a Spartina hybrid. Ecological Applications, 16 , 1391-1404. http://dx.doi.org/10.1890/1051-0761(2006)016[1391:MGMOBF]2.0.CO;2

Nielsen, T., \& Andersen, F.Ø. (2003). Phosphorous dynamics during decomposition of mangrove (Rhizophora apiculata) leaves in sediments. Journal of Experimental Marine Biology and Ecology, 293, 73-88. http://dx.doi.org/10.1016/S0022-0981(03)00200-4

Nordhaus, I., \& Wolff, M. (2007). Feeding ecology of the mangrove crab Ucides cordatus (Ocypodidae): food choice, food quality and assimilation efficiency. Marine Biology, 151, 
1665-1681. http://dx.doi.org/10.1007/s00227-006-0597-5

Odum, W. E., \& Heald, E. J. (1972). Trophic analyses of an estuarine mangrove community. Bulletin of Marine Science, 22(3), 671-738.

Paul, A. (2002). Coastal Geomorphology and Environment. ACB publications, Kolkata, India.

Rao, R. G., Woitchik, A. F., Goeyens, L., van Riet, A., Kazunga, J., \& Dehairs, F. (1994). Carbon, nitrogen contents and stable carbon isotope abundance in mangrove leaves from an east African coastal lagoon. Aquatic Botany, 47, 175- 183. http://dx.doi.org/10.1016/0304-3770(94)90012-4

Ravichandran, S., \& Kannupandi, T. (2004). Biochemical changes in decomposing leaves and crabs of Pichavaram mangroves. Biochemical and Cellular Archives, 24(3).79- 88.

Riisgard, H. U., \& Kamermans, P. (2001). Switching between deposit and suspension feeding in coastal zoobenthos. In: Ecological comparisons of sedimentary shores, K. Reise (Ed.). Ecological studies. Springer, Berlin, Vol. 151, 73-100.

Robertson, A. I. (1988). Decomposition of mangrove leaf litter in tropical Australia. Journal of Experimental Marine Biology and Ecology, 116. 235-247. http://dx.doi.org/10.1016/0022-0981(88)90029-9

Robertson, A. I., \& Daniel, A. (1989). The influence of crabs on litter processing in high intertidal mangrove forests in tropical Australia. Oecologia, 78(2).191-198. http://dx.doi.org/10.1007/BF00377155

Semeniuk, V. (2008). Holocene sedimentation, stratigraphy, biostratigraphy, and history of the Canning Coast, north-western Australia. Journal of the Royal Society of Western Australia, Supplement to Volume 91. Part 1, March 2008.

Shin, P. K. S., Yiu , M. W., \& Cheung, S. G. (2004). Behavioural adaptations of the fiddler crabs Uca vocans borealis (crane) and Uca lactea lactea (De Haan) for coexistence on an intertidal shore. Marine and freshwater Behaviour and Physiology, 37(3), 147-160. http://dx.doi.org/10.1080/10236240400006117

Silva, C. A. R., Oliveira, S. R., Rego, R. D. P., \& Mozeto, A. A. (2007). Dynamics of phosphorous and nitrogen through litter fall and decomposition in a tropical mangrove forest. Marine Environment Research, 64, 524-534. http://dx.doi.org/10.1016/j.marenvres.2007.04.007

Skov, M. W., \& Hartnoll, R. G. (2002). Paradoxical selective feeding on a low-nutrient diet: Why do mangrove crabs eat leaves? Oecologia, 131. http://dx.doi.org/10.1007/s00442-001-0847-7

Smith III, T. J., Boto, K. G., Frusher, S. D., \& Giddins, R. L. (1991). Keystone species and mangrove forest dynamics: the influence of burrowing crabs on soil nutrient status and forest productivity. Estuarine, Coastal and Shelf Science, 33. 419-432. http://dx.doi.org/10.1016/0272-7714(91)90081-L 


\section{Macrothink}

Statsoft, (2001). STATISTICA: data analysis software system, version 6.0. Tulsa, StatSoft, Inc.

Stewart, B. A., \& Davies, B. R. (1989). The influence of different litterbag designs on the breakdown of leaf material in a small mountain stream. Hydrobiologia, 183. 173-177. http://dx.doi.org/10.1007/BF00018722

Twilley, R. R., Pozo, M., Garica, V. H., Rivera-Monroy, V. H., Zambrano, R., \& Bodero, A. (1997). Litter dynamics in riverine mangrove forests in the Guayas River estuary, Ecuador. Oecologia, 111, 109-122. http://dx.doi.org/10.1007/s004420050214

Warren, J. H., \& Underwood, A. J. (1986). Effects of burrowing crabs on the topography of mangrove swamps in New South Wales. Journal of Experimental Marine Biology and Ecology, 102, 223-35. http://dx.doi.org/10.1016/0022-0981(86)90178-4

Woods, C. M. C. (1993). Natural diet of the crab Notomithrax ursus (brachyuran, Majidae) at Oaro, South Island, New Zealand". New Zealand Journal of Marine and Freshwater Research, 27(3), 309-315. http://dx.doi.org/10.1080/00288330.1993.9516571

Zar, J. H. (1999). Biostatistical Analysis (4th edition). Prentice Hall, USA.

Zeil, J., \& Layne, J. E. (2002). Path integration in fiddler crabs and its relation to habitat and social life. In: Wiese K (ed.) Crustacean experimental systems in neurobiology. Springer, Berlin, Heidelberg, New York, pp. 227-24. http://dx.doi.org/10.1007/978-3-642-56092-7_13

\section{Copyright Disclaimer}

Copyright reserved by the author(s).

This article is an open-access article distributed under the terms and conditions of the Creative Commons Attribution license (http://creativecommons.org/licenses/by/3.0/). 